\title{
Don David Stitchkin, nuevo Rector de la Universidad de Concepción
}

En el Claustro Pleno de la Universidad de Concepción, del 28 de abril último, convocado para designar Rector en reemplazo de don Enrique Molina, fué elegido por amplia mayoría el señor David Stitchkin Branover.

El señor Stitchkin exhibe una fecunda y dilatada labor en la docencia universitaria y en el ejercicio de su profesión de abogado. Nacido en Santiago de Chile en 1912, sus estudios de segunda enseñanza los realizó en el Liceo de Aplicación y los universitarios en la Escuela de Derecho y de Ciencias Sociales de la Universidad de Chile, al término de los cuales, por sus excelentes calificaciones se le otorgó el Premio Gormaz correspondiente al bienio 1935-1937. Desde los años 1938 al 1946 fué profesor de Derecho Civil Profundizado y Comparado y director del Seminario de Derecho Privado en la Universidad de Concepción. Fundó el teatro de esa Universidad y ha sido director del Teatro Experimental de la Universidad de Chile. Ha desempeña- 
do, además, los cargos de abogado de la Caja de Empleados Públicos y Periodistas, abogado de la Contraloría General de la República y fiscal de la Caja de la Habitación Popular. Actualmente es profesor extraordinario en la Escuela de Derecho y Ciencias Sociales de la Universidad de Chile y miembro del Consejo General del Colegio de Abogados. Es autor de una obra, El mandato civil, y de numerosas publicaciones aparecidas en la "Revista de Derecho y Jurisprudencia".

Llega a la Rectoría de la Universidad de Concepción en la plenitud de su actividad intelectual y al recibir el legado de docencia y de cultura de don Enrique Molina, su espíritu realizador mantendrá el prestigio logrado por este instituto de estudios superiores, imprimiéndole el dinamismo que exigen las universidades modernas.

"Atenea" se complace en anunciar a sus numerosos lectores del mundo hispánico la designación del señor David Stitchkin Branover como Rector de la Universidad de Concepción. 


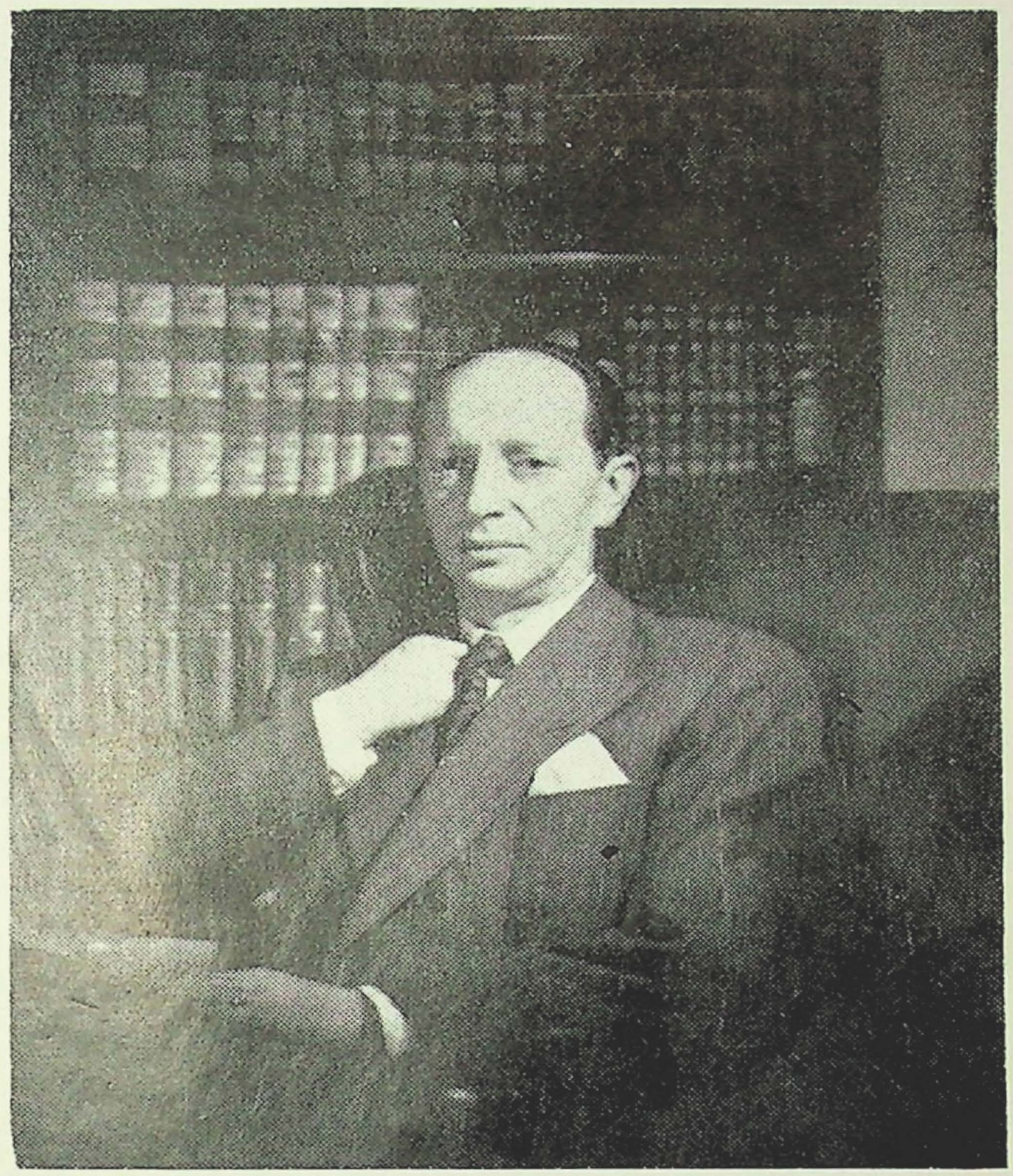

Don David Stitchkin, Rector de la Universidad de Concepción 